\title{
OSJETLJIVOST TLA NA PROPUŠTANJE ONEČIŠĆIVAČA I RANJIVOST PODZEMNE VODE NA ONEČIŠĆENJE U NIZINSKOM PODRUČJU MEĐIMURSKE ŽUPANIJE
}

\author{
SENSITIVITY OF SOIL TO LEACHING OF POLLUTANTS \\ AND VULNERABILITY OF GROUND WATER TO POLLUTION \\ IN THE LOWLAND OF MEĐIMURJE COUNTY
}

\section{Ž. Vidaček}

\section{SAŽETAK}

U ovom radu o osjetljivosti tla na propuštanje onečišćivača i ranjivosti podzemne vode na onečišćenje $\mathrm{s}$ površine tla, korišten je dio rezultata petogodišnjih istraživanja nizinskog područja Međimurske županije, Vidaček i sur. 2008. U donjem dijelu Međimurja ima najviše obradivih površina. S agroekološkog gledišta, to su površine potencijalno visokog stupnja onečišćenja agrokemikalijama. Kvartarne sedimente pokrivaju automorfna i hidromorfna tla različite teksture, strukture i propusnosti za vodu. Vodonosni horizont nizinskog područja županije se sastoji od dobro granuliranog šljunka $\mathrm{s}$ različitim postotkom pijeska. Od ukupno 42.893,5 hektara poljoprivrednog zemljišta, nalazimo sljedeće klase osjetljivosti tla na potencijalno propuštanje onečišćivača $u$ podzemnu vodu: tla II. klase slabe osjetljivosti $1.496,5$ ha, tla III. klase umjerene osjetljivosti $6.157,6$ ha i tla IV. klase jake osjetljivosti 20.311,9 hektara. Vidi kartu u prilogu na kraju teksta. Najplići otvoreni vodonosni horizont je u nizinskom području županije jako ranjiv na onečišćenje $\mathrm{s}$ površine tla. Godišnje izmjerene količine procijeđene vode iz lizimetara, sa ili bez onečišćivača u pet godišnjem razdoblju, variraju od 75,8-281,5 mm. Količine ispranog mineralnog dušika su najveće u natapanju nasada jabuka 13,5 do 47,7 kg N/ha. Pri uzgoju ratarskih kultura, dominantno kukuruza, te vrijednosti variraju u vrlo širokom rasponu od 7,2 $\mathrm{kg} \mathrm{N} / \mathrm{ha}$ do $30,5 \mathrm{~kg} \mathrm{~N} / \mathrm{ha}$.

Ključne riječi: tlo, podzemna voda, onečišćenje, mineralni dušik, lizimetri 
Ž. Vidaček: Osjetljivost tla na propuštanje onečišćivača i ranjivost podzemne vode na onečišćenje u nizinskom području Međimurske županije

\begin{abstract}
This work on soil sensitivity to leaching of pollutants and groundwater vulnerability to pollution is a part of a five-year research on the lowland area of Međimurje County by Vidaček at all. 2008. In the lower part of Međimurje most of the land is arable. From the agroecological point of view, these are areas of potentially high degree of pollution by agrochemicals. Aquifers are covered by automorphic and hydromorphic soils of different texture and water permeability. The aquifer horizon consists of well-grained gravel with different percentage of sand. Of the total area of gross $42,893.5$ hectares, we have the following soil sensitivity classes to potentially contaminate groundwater: soil of II. classes of weak sensitivity 1,496.5 ha, soil of III. moderate sensitivity classes, $6.157,6$ ha and soil of IV. high sensitivity class, 20,311.9 hectares. See a map at the end of the text. The shallowest open water horizon in the lowland area of the county is highly vulnerable to pollution from the surface of the soil. Annual measured quantities of leached water from lysimeter in the five year period vary from 75.8 to $281.5 \mathrm{~mm}$. Quantities of leached mineral nitrogen are the highest in apple plantation 13.5 to $47.7 \mathrm{~kg} \mathrm{~N} / \mathrm{ha}$. When cultivating field crops, predominantly corn, these values vary in a very wide range of $7.2 \mathrm{~kg} \mathrm{~N} /$ ha to $30.5 \mathrm{~kg} \mathrm{~N} / \mathrm{ha}$.
\end{abstract}

Key words: soil, groundwater, pollution, mineral nitrogen, lysimeters

\title{
UVOD
}

Problemi zaštite okoliša, uključujući i akvatične ekosustave, intenzivnije se rješavaju zadnjih 35 godina. Aktivnosti su vezane uz Nitratnu direktivu 1991., Helsinšku konvenciju o zaštiti i uporabi prekograničnih vodotokova i međunarodnih jezera 1992., Konvenciju i nacionalni program ublažavanja posljedica suše i suzbijanja degradacije zemljišta 1994-2001., Konvenciju o korištenju voda rijeke Dunava 1997., Direktivu Europskog parlamenta i Vijeća o zaštiti podzemnih voda od onečišćenja i pogoršanja kakvoće, koja posebno uključuje kriterije za procjenu dobrog kemijskog stanja podzemnih voda 2003-2006.

U ovom radu objavljen je dio rezultata petogodišnjih istraživanja osjetljivosti tla na propuštanje onečišćivača i ranjivosti podzemne vode na onečišćenje, Vidaček i sur. (2008.). 
Ž. Vidaček: Osjetljivost tla na propuštanje onečišćivača i ranjivost podzemne vode na onečišćenje u nizinskom području Međimurske županije

1. Osjetljivost tla na propuštanje onečišćivača i ranjivost podzemne vode na onečišćenje

\subsection{Poljoprivredno zemljište i struktura biljne proizvodnje}

Prema podacima Državne geodetske uprave i područnog ureda za katastar Čakovec, u donjem dijelu Međimurja ima najviše 11.182,16 ha oranica $(69,88 \%)$, voćnjaka 552,52 ha $(3,45 \%)$, livada $3.720,89$ ha $(23,25 \%)$, pašnjaka 523,10 ha $(3,27 \%)$ i vinograda 22,25 ha $(0,15 \%)$. Najveće su površine oranica s kukuruzom 6.712,49 (60,03\%) i ozimom pšenicom 2.046,33 (18,30\%), tablica 1 . S agroekološkog gledišta, uključujući 552,52 ha voćnjaka, to su poljoprivredne površine $\mathrm{s}$ potencijalno visokim stupnjem onečišćenja agrokemikalijama i mogućnošću onečišćenja podzemnih voda.

Tablica 1. Struktura biljne proizvodnje na oranicama

Table 1 Structure of plant production on arable land

\begin{tabular}{|c|c|}
\hline Kultura-Culture & Hektari+ \% \\
\hline Ozima pšenica-Winter wheat & $2.046,33 \quad 18,30$ \\
\hline Kukuruz-Corn & $6.712,49 \quad 60,03$ \\
\hline Ostale žitarice-Other cereals & $745,85 \quad 6,67$ \\
\hline Šećerna repa- suger beet & $218,05 \quad 1,95$ \\
\hline Uljana repica-Oil rape & $249,00 \quad 2,23$ \\
\hline Krumpir-Potato & $627,70 \quad 5,61$ \\
\hline Uljne tikve- Oil pumpkins & $276,64 \quad 2,47$ \\
\hline Povrće-Vegetable & $306,07 \quad 2,74$ \\
\hline UKUPNO-Total & $11.182,16 \quad 100,00$ \\
\hline
\end{tabular}

Izvor: Milorad Šubić-vlastita procjena prema prijavi šteta - suše u 2007.;

Source: Milorad Šubić's own estimation of damage claims - drought in 2007.

\subsection{Geološko-hidrogeološki uvjeti}

U nizinskom području Međimurske županije prisutni su kvartarni sedimenti. $\mathrm{Na}$ površini dominiraju pijesci s primjesom gline u izmjeni s pjeskovitim šljunkom ili u pedološkom izričaju to su ilovasti pijesak, ilovasta glina, praškasta ilovača, praškasto glinasta ilovača sa ili bez skeleta, različite uslojenosti, u prosjeku $0,5-3,0 \mathrm{~m}$ debljine iznad vodonosnog horizonta 70-150 m debljine.

Vodonosni horizont se sastoji od dobro granuliranog šljunka s različitim postotkom pijeska. Najplići vodonosni horizont je dobre izdašnosti i prosječne vrijednosti hidrauličke provodljivosti $7,1 \times 10^{-1} \mathrm{~cm} / \mathrm{s}$. 
Ž. Vidaček: Osjetljivost tla na propuštanje onečišćivača i ranjivost podzemne vode na onečišćenje u nizinskom području Međimurske županije

\subsection{Zastupljenost tala i načini vlaženja tla}

Poljoprivredno zemljište $\mathrm{u}$ nizinskom području nalazi se pretežno na automorfnim tlima s vlaženjem samo oborinama i hidromorfnim tlima s viškom površinske ili/i podzemne vode ${ }^{1}$ unutar referentne dubine 2,0 metra Manje su površine hidromelioriranih hidromorfnih tala drenažom $\mathrm{s}$ normom odvodnje oko 0,5 metara, te automorfnih i hidromorfnih tala s promijenjenim vodnim režimom u području utjecaja hidroelektrana Čakovec i Dubrava.

Automorfna tla poljoprivrednog zemljišta, uključuju:

- rendzinu i ranker na pijesku i/ili šljunku i lesivirana na pijesku, vlaženje vrlo brzo procjednom oborinskom vodom ${ }^{2}, \mathrm{~K}>4,8 \mathrm{~m} / \mathrm{dan}$

- smeđa kisela i eutrična tla na šljunku, lesu i pijesku, ilovasta, praškasto glinasto ilovasta, mjestimično skeletoidna, te aluvijalna neoglejena i neplavljena tla na pijesku i šljunku pjeskovito ilovasta i ilovasta, vlaženje brzo procjednom oborinskom vodom $\mathrm{K}>1,4-4,8 \mathrm{~m} / \mathrm{dan}$

Hidromorfna tla poljoprivrednog zemljišta, uključuju:

- aluvijalno oglejena tla povremeno plavljena na pijesku i šljunku, pjeskovito ilovasta, ilovasta, vlaženje brzo ili umjereno brzo procjednom $\mathrm{K}=0,5-4,8 \mathrm{~m} /$ dan + plitkom $0,5-1,0 \mathrm{~m}$ ili srednje dubokom 1,0-2,0 $\mathrm{m}$ podzemnom vodom maksimalne razine

- semiglejna tla, vlaženje umjereno brzom procjednom vodom $\mathrm{K}=0,5-1,4 \mathrm{~m} / \mathrm{dan}+$ srednje dubokom podzemnom vodom 1,0-2,0 $\mathrm{m}$ maksimalne razine

- močvarno glejno hipoglejno, vlaženje umjereno brzom procjednom vodom $\mathrm{K}=0,5-1,4 \mathrm{~m} / \mathrm{dan}+$ vrlo plitkom ili plitkom podzemnom vodom 0-1,0 m maksimalne razine

- močvarno glejno amfiglejno, vlaženje ekstremno sporo procjednom vodom $\mathrm{K}<0,01 \mathrm{~m} /$ dan + srednje dubokom podzemnom vodom 1,0-2,0 m maksimalne razine

\footnotetext{
${ }^{1} \mathrm{U}$ hidropedološkoj praksi, podzemnu vodu prema maksimalnoj razini dijelimo na: plitku podzemnu vodu 0-100 cm, srednje duboku podzemnu vodu $100-200 \mathrm{~cm}$ i duboku podzemnu vodu $>200 \mathrm{~cm}$

${ }^{2}$ Propusnost ili hidrauličku vodljivost $\mathrm{u}$ izrazu brzine procjeđivanja površinske vode (oborine i/ili poplave) dijelimo na: vrlo brzo procjednu $\mathrm{K}>4,8 \mathrm{~m} / \mathrm{dan}$, brzo procjednu $\mathrm{K}=1,4-4,8 \mathrm{~m} / \mathrm{dan}$, procjednu $K=0,5-1,4 \mathrm{~m} /$ dan, sporo procjednu $K=0,01-0,5 \mathrm{~m} /$ dan, stagnirajuću $K<0,01 \mathrm{~m} /$ dan.
} 
Ž. Vidaček: Osjetljivost tla na propuštanje onečišćivača i ranjivost podzemne vode na onečišćenje u nizinskom području Međimurske županije

- Pseudoglej-glejno tlo, vlaženje vrlo sporo procjednom vodom $\mathrm{K}=0,01-0,05 \mathrm{~m} /$ dan + plitkom $0,5-0,1 \mathrm{~m} /$ dan ili srednje dubokom podzemnom vodom 1,0-2,0 m maksimalne razine

$\mathrm{Na}$ području utjecaja hidroelektrana Čakovec i Dubrava, otklonjena je mogućnost poplava na dijelu područja hidrosustava. Funkcioniranje obodnih kanala uz akumulacijsko jezero, omogućava odvodnju močvarnih tala. Uz strojarnicu je sniženje nivoa podzemne vode za 1,5-2,0 m. To je negativan utjecaj energetskog objekta na biljnu proizvodnju zbog manjeg prihranjivanja agrološkog profila kapilarnom vodom iz podzemlja, Vidaček Ž. i sur. 1984.

\subsection{Ocjena osjetljivosti tla na propuštanje onečišćivača}

\subsubsection{Kriteriji ocjenjivanja}

Tla koja brzo propuštaju onečišćivače u podzemnu vodu su osjetljiva tla. Osjetljivost tla ovisi o propusnosti ili hidrauličkoj vodljivosti (m/dan), režimu podzemne vode (razini i trajanju), sadržaju organske tvari-humusu $(\%)^{3}$ i teksturi (\% gline-čestice manje od $2 \mu \mathrm{m}$ promjera).

$\mathrm{U}$ tom smislu ocjenjujemo potencijal ispiranja tvari iz tla procjednom vodom i potencijal sorpcije tvari ili zadržavanja tvari na mineralnim i/ili organskim česticama tla. Indikatori potencijala ispiranja tvari iz tla su vodopropusnost $(\mathrm{m} / \mathrm{dan})$ i maksimalna razina podzemne vode $(\mathrm{cm})$, a indikatori potencijala sorpcije tvari u tlu su tekstura i sadržaj humusa

\subsubsection{Rezultati ocjenjivanja}

U nizinskom području Međimurske županiji, ukupne bruto površine 42.893,5 hektara, nalazimo tri klase osjetljivosti tala na propuštanje onečišćivača u podzemnu vodu, tablica 2 i karta osjetljivosti tala u prilogu: II. klasa - tla slabe osjetljivosti, bruto 1.496,5 ha, III. klasa - tla umjerene osjetljivosti, bruto $6.157,6$ ha i IV. klasa - tla jake osjetljivosti, bruto 20.311,9 hektara. Kako se radi o karti sitnog mjerila i većoj složenosti terena, na karti je izdvojena klasa $\mathrm{V}$ - tla područja mješovite osjetljivosti, bruto 14.927,5 hektara. Karta je izrađena u digitalnom obliku i mjerilu 1:200 000. Izvor podataka je Hidropedološka karta Hrvatske, mjerila 1:300 000, Vidaček Ž., i sur. 2003. U radu su korišteni GIS alati Arc View i Arc Info.

\footnotetext{
${ }^{3}$ Ocjena sadržaja organske tvari-humusa je kako slijedi: vrlo slabo humozna tla do $1 \%$, slabo humozna $1-3 \%$, dosta humozna $3-5 \%$, jako humozna $5-10 \%$ i vrlo jako humozna $>10 \%$ humusa.
} 
Ž. Vidaček: Osjetljivost tla na propuštanje onečišćivača i ranjivost podzemne vode na onečišćenje u nizinskom području Međimurske županije

Tablica 2. Osjetljivosti tla na propuštanje onečišćivača s površine tla u nizinskom području

Table 2 Soil sensitivity to leaching of pollutants from the soil surface in the lowland area

\begin{tabular}{|c|c|c|c|c|c|c|}
\hline \multicolumn{3}{|c|}{$\begin{array}{l}\text { Klase osjetljivosti tla - } \\
\text { Classes of soil sensitivity }\end{array}$} & \multicolumn{2}{|c|}{$\begin{array}{l}\text { Potencijal ispiranja-- } \\
\text { Leaching potential }\end{array}$} & \multicolumn{2}{|c|}{$\begin{array}{l}\text { Potencijal sorpcije - } \\
\text { Sorption potential }\end{array}$} \\
\hline Broj-No & $\begin{array}{c}\text { **Intenzitet } \\
\text { Intensity }\end{array}$ & Bruto ha & $\begin{array}{l}\text { Vodopropusnost } \\
\text { m/dan, } \\
\text { Water permeability }\end{array}$ & $\begin{array}{c}\text { Podzemna } \\
\text { voda, cm } \\
\text { Groundwater }\end{array}$ & $\begin{array}{l}\text { Tekstura } \\
\text { Texture* }\end{array}$ & $\begin{array}{c}\text { Humus, } \\
\%\end{array}$ \\
\hline II & $\begin{array}{c}\text { Slaba } \\
\text { osjetljivost }\end{array}$ & $1.496,5$ & $\begin{array}{l}\text { Procjedna voda } \\
(0,5-1,4)\end{array}$ & $\begin{array}{l}\text { Duboka } \\
(>200)\end{array}$ & $* \mathrm{I}$ & $2-3$ \\
\hline III & $\begin{array}{c}\text { Umjerena } \\
\text { osjetljivost }\end{array}$ & $6.157,6$ & $\begin{array}{c}\text { Procjedna voda } \\
\quad(0,5-1,4)\end{array}$ & $\begin{array}{l}\text { Srednje duboka } \\
\quad(100-200)\end{array}$ & $\begin{array}{c}\text { PrI- } \\
\text { mjestimično } \\
\text { skeletoidna }\end{array}$ & $2-3$ \\
\hline IV & $\begin{array}{c}\text { Jaka } \\
\text { osjetljivost }\end{array}$ & $20.311,9$ & $\begin{array}{c}\text { Brzo procjedna } \\
\quad(1,4-4,8)\end{array}$ & $\begin{array}{l}\text { Plitka } \\
(0-100)\end{array}$ & $\begin{array}{c}\text { PjI, PrI } \\
\text { mjestimično } \\
\text { skeletoidna }\end{array}$ & $2-5$ \\
\hline V & $\begin{array}{c}\text { Mješovita } \\
\text { osjetljivost }\end{array}$ & $14.927,5$ & $\begin{array}{c}\text { Procjedna voda } \\
(0,5-1,4) \\
\text { i brzo procjedna } \\
(1,4-4,8)\end{array}$ & $\begin{array}{c}\text { Plitka, } \\
\text { srednje duboka } \\
\text { i duboka } \\
(0-200 \mathrm{i}>200)\end{array}$ & PrI, PjI, I, GI & $2-10$ \\
\hline \multicolumn{2}{|c|}{ Ukupno - Total } & $42.893,5$ & & & & \\
\hline
\end{tabular}

*I-ilovača-loam; PjI-pjeskovita ilovača-sandy loam; PrI-praškasta ilovača-silty loam; GI-glinasta ilovača-clay loam; mjestimično skeletno-in places gravel;

** Slaba, umjerena, jaka i miješana osjetljivost - Slightly moderately, highly and mixed sensitivity to leaching by pollutants from the soil surface

1.4.3. Vodonosni horizont i ocjena ranjivosti podzemne vode na onečišćenje s površine tla

Otvoreni vodonosni horizont se sastoji od dobro granuliranog šljunka s različitim postotkom pijeska, debljine 100-150 metara, umjerene hidrauličke propusnosti za vodu. U takvim uvjetima vodonosnika podzemna voda u nizinskom području županije je potencijalno jako ranjiva na onečišćenje s površine tla. 
Ž. Vidaček: Osjetljivost tla na propuštanje onečišćivača i ranjivost podzemne vode na onečišćenje u nizinskom području Međimurske županije

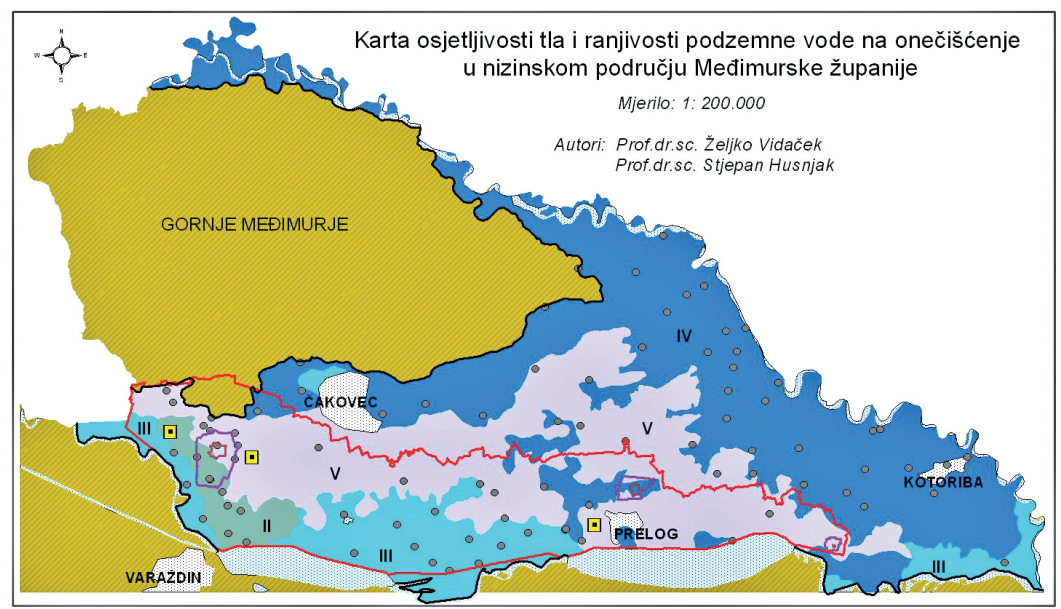

\begin{tabular}{|c|c|c|c|c|c|c|}
\hline \multicolumn{3}{|c|}{ Klasa osjetljivosti tla } & \multicolumn{2}{|c|}{ Indikatori potencijala ispiranja tvari iz tla } & \multicolumn{2}{|c|}{$\begin{array}{l}\text { Indikatori potencijala } \\
\text { sorpcije tvari u tlu }\end{array}$} \\
\hline $\begin{array}{l}\text { Broj i } \\
\text { oznaka } \\
\text { na karti }\end{array}$ & Stupanj & $\begin{array}{c}\text { Bruto, } \\
\text { ha }\end{array}$ & $\begin{array}{l}\text { Vodopropusnost } \\
\qquad \mathrm{K}=\mathrm{m} / \mathrm{dan}\end{array}$ & $\begin{array}{l}\text { Maksimalna razina } \\
\text { podzemne vode, } \mathrm{cm}\end{array}$ & Tekstura & Humus, \% \\
\hline ॥ & \begin{tabular}{|c|} 
Slaba \\
osjetljivost
\end{tabular} & $1.496,5$ & $\begin{array}{c}\text { Procjedna voda } \\
(0,5-1,4)\end{array}$ & $\begin{array}{l}\text { Duboka } \\
(>200)\end{array}$ & 1 & $2-3$ \\
\hline III & $\begin{array}{l}\text { Umjerena } \\
\text { osjetljivost }\end{array}$ & $6.157,6$ & $\begin{array}{c}\text { Procjedna voda } \\
(0,5-1,4)\end{array}$ & $\begin{array}{l}\text { Srednje duboka } \\
(100-200)\end{array}$ & $\begin{array}{l}\text { Prl-mjestimično } \\
\text { skeletoidna }\end{array}$ & $2-3$ \\
\hline IV & $\begin{array}{c}\text { Jaka } \\
\text { osjetljivost }\end{array}$ & $20.311,9$ & $\begin{array}{c}\text { Brzo procjedna } \\
\text { voda }(1,4-4,8)\end{array}$ & $\begin{array}{l}\text { Plitka } \\
(0-100)\end{array}$ & $\begin{array}{c}\text { Pjl, Prl } \\
\text { mjestimično } \\
\text { skeletoidna }\end{array}$ & $2-5$ \\
\hline V & $\begin{array}{l}\text { Mješovita } \\
\text { osjetljivost }\end{array}$ & $14.927,5$ & $\begin{array}{c}\text { Procjedna }(0,5-1,4) \\
\text { i brzo procjedna } \\
\text { voda }(1,4-4,8)\end{array}$ & $\begin{array}{c}\text { Plitka, srednje } \\
\text { duboka i duboka } \\
(0-200 \text { i >200) }\end{array}$ & $\mathrm{Prl}, \mathrm{Pjl}, \mathrm{I}, \mathrm{GI}$ & $2-10$ \\
\hline \multicolumn{2}{|c|}{ Ukupno } & $42.893,5$ & & & & \\
\hline & Veća naselja & & & & & \\
\hline & Vode & & & & & \\
\hline
\end{tabular}

Tumač: I-jlovača; Pjl-pjeskovita ilovača; PrI-praškasta ilovača; GI-glinasta ilovača; Skeletnost-oko $50 \%$ valutica šljunka

- Pjezometri

$\wedge$ Vodozaštitna područja (I. zona)

Vodozaštitna područja (II. zona)

Vodozaštitna područja (III. zona)

曰 Lokacije tenziometrijskih i lizimetrijskih mjerenja, 2003-2007 godina

GIS obrada: Prof.dr.sc. Stjepan Husnjak

Tisak: Agronomski fakultet Sveučilišta u Zagrebu, Zavod za pedologiju, 2008.

Map of soil sensitivity to leaching by pollutants and groundwater vulnerability to pollution in the lowland area of Medimurje county 
Ž. Vidaček: Osjetljivost tla na propuštanje onečišćivača i ranjivost podzemne vode na onečišćenje u nizinskom području Međimurske županije

2. Rezultati stacionarnih istraživanja

2.1. Kontrolna polja

\subsubsection{Kontrolno polje Nedelišće}

Površina voćnjaka je 80 ha. Kontrola je organizirana na dijelu table 2 , sorta jabuke je Idared na podlozi M-106, razmaka sadnje 4,5 x 2,8 m, broj voćaka/ha 816 komada, a godina sadnje 1987. Nasad jabuka je na antropogeniziranom eutričnom praškasto ilovastom tlu. Dubina do šljunka i/ili pijeska je dublje od $100 \mathrm{~cm}$.

\subsubsection{Kontrolno polje Gornji Hrašćan}

Kontrolno polje je na dijelu oranice 0,43 ha. Tlo je semiglej aluvijalno, ilovasto tlo. Dubina do šljunka i/ili pijeska je dublje od $165 \mathrm{~cm}$. Ratarska proizvodnja.

\subsubsection{Kontrolno polje Prelog}

Površina kontrolnog polja je na dijelu oranice 3,25 ha. Tlo je hipoglej, djelomično hidromelioriran. Tekstura tla je ilovasta. Dubina do šljunka $\mathrm{i} / \mathrm{ili}$ pijeska je dublje od $90 \mathrm{~cm}$. Ratarska proizvodnja.

\subsection{Procijeđene vode iz lizimetara}

Vrijednosti mjesečnih i godišnjih količina procijeđenih voda iz lizimetara su za antropogenizirano eutrično tlo kontrolnog polja Nedelišće, semiglejno tlo kontrolnog polja Gornji Hraščan i hipoglejno djelomično hidromeliorirano tlo kontrolnog polja Prelog. Podaci su dobiveni direktnim mjerenjem procijeđenih oborina + natapanje iz lizimetra na kontrolnom polju Nedelišće i samo procijeđenih oborina za kontrolna polja Gornji Hraščan i Prelog. Prilično promjenjive količine procijeđene vode, rezultat su sezonskih hidroloških, hidropedoloških i agrotehničkih uvjeta. U praktičnom smislu, te količine procijeđene vode prihranjuju podzemnu vodu sa ili bez onečišćivaća, tablica 3. 
Ž. Vidaček: Osjetljivost tla na propuštanje onečišćivača i ranjivost podzemne vode na onečišćenje u nizinskom području Međimurske županije

Tablica 3. Mjesečne i godišnje količine procijeđene vode iz lizimetara, mm

Table 3 Monthly and yearly amount of leaching water from lysimeters

\begin{tabular}{|l|c|c|c|c|c|c|c|c|c|c|c|c|c|}
\hline God. & I & II & III & IV & V & VI & VII & VIII & IX & X & XI & XII & God. \\
\hline \multicolumn{10}{|c|}{ Kontrolno polje - Control field Nedelišće* } \\
\hline 2004. & 2,8 & 4,0 & 24,7 & 16,3 & 19,3 & 47,2 & 14,6 & 58,7 & 5,9 & 26,0 & 11,8 & 3,5 & $\mathbf{2 2 5 , 1}$ \\
\hline 2005. & 1,0 & 8,4 & 18,6 & 32,1 & 10,5 & 46,3 & 16,6 & 10,3 & 2,5 & 2,2 & 0,0 & 16,3 & $\mathbf{1 4 2 , 8}$ \\
\hline 2006. & 0,0 & 15,2 & 13,9 & 12,5 & 15,0 & 32,0 & 15,5 & 22,2 & 5,1 & 0,0 & 0,0 & 0,0 & $\mathbf{1 2 6 , 3}$ \\
\hline 2007. & 2,8 & 0,0 & 14,6 & 48,5 & 26,0 & 56,2 & 56,2 & 56,5 & 12,9 & 0,8 & 3,4 & 3,6 & $\mathbf{2 8 1 , 5}$ \\
\hline sv** & $\mathbf{1 , 7}$ & $\mathbf{6 , 9}$ & $\mathbf{1 8 , 0}$ & $\mathbf{2 7 , 4}$ & $\mathbf{1 7 , 7}$ & $\mathbf{4 5 , 4}$ & $\mathbf{2 5 , 7}$ & $\mathbf{3 6 , 9}$ & $\mathbf{6 , 6}$ & $\mathbf{7 , 3}$ & $\mathbf{3 , 8}$ & $\mathbf{5 , 9}$ & $\mathbf{1 9 3 , 9}$ \\
\hline \multicolumn{10}{|c|}{ Kontrolno polje - Control field Gornji Hrašćan } \\
\hline 2004. & 0,0 & 0,0 & 14,5 & 18,3 & 3,5 & 11,0 & 4,0 & 0,0 & 0,0 & 12,4 & 14,1 & 10,2 & $\mathbf{8 8 , 0}$ \\
\hline 2005. & 4,1 & 0,0 & 12,9 & 13,4 & 1,6 & 1,2 & 13,8 & 17,2 & 19,3 & 5,1 & 8,1 & 7,9 & $\mathbf{1 0 4 , 6}$ \\
\hline 2006. & 0,0 & 2,6 & 8,6 & 12,7 & 23,1 & 10,3 & 6,1 & 17,6 & 4,3 & 2,8 & 4,4 & 2,6 & $\mathbf{9 5 , 1}$ \\
\hline 2007. & 8,7 & 3,9 & 17,2 & 2,6 & 10,2 & 0,0 & 0,0 & 0,0 & 5,2 & 13,2 & 14,8 & 0,0 & $\mathbf{7 5 , 8}$ \\
\hline sv*** & $\mathbf{3 , 2}$ & $\mathbf{1 , 6}$ & $\mathbf{1 3 , 3}$ & $\mathbf{1 1 , 8}$ & $\mathbf{9 , 6}$ & $\mathbf{5 , 6}$ & $\mathbf{6 , 0}$ & $\mathbf{8 , 7}$ & $\mathbf{7 , 2}$ & $\mathbf{8 , 4}$ & $\mathbf{1 0 , 4}$ & $\mathbf{5 , 2}$ & $\mathbf{9 0 , 9}$ \\
\hline \multicolumn{10}{|c|}{ Kontrolno polje - Control field Prelog } \\
\hline 2004. & 20,3 & 10,1 & 36,8 & 36,2 & 6,2 & 0,0 & 0,0 & 15,1 & 8,2 & 30,4 & 21,0 & 13,4 & $\mathbf{1 9 7 , 7}$ \\
\hline 2005. & 9,0 & 7,6 & 24,1 & 27,2 & 0,4 & 0,1 & 14,9 & 30,5 & 20,3 & 5,9 & 0,0 & 18,6 & $\mathbf{1 5 8 , 6}$ \\
\hline 2006. & 0,0 & 9,6 & 14,9 & 19,0 & 16,1 & 26,8 & 0,0 & 20,2 & 2,1 & 0,0 & 4,4 & 3,3 & $\mathbf{1 1 6 , 4}$ \\
\hline 2007. & 9,6 & 4,2 & 16,8 & 11,8 & 0,0 & 0,0 & 0,0 & 8,6 & 25,4 & 13,5 & 16,6 & 13,1 & $\mathbf{1 1 9 , 6}$ \\
\hline sv** & $\mathbf{9 , 7}$ & $\mathbf{7 , 9}$ & $\mathbf{2 3 , 2}$ & $\mathbf{2 3 , 6}$ & $\mathbf{5 , 7}$ & $\mathbf{6 , 7}$ & $\mathbf{3 , 7}$ & $\mathbf{1 8 , 6}$ & $\mathbf{1 4 , 0}$ & $\mathbf{1 2 , 5}$ & $\mathbf{1 0 , 5}$ & $\mathbf{1 2 , 1}$ & $\mathbf{1 4 8 , 1}$ \\
\hline
\end{tabular}

*oborine+natapanje u nasadu jabuka - rainfall + irrigation in apple plantation;

**srednja vrijednost - mean value

\subsection{Potencijalni rizik onečišćenja podzemne vode mineralnim dušikom}

Količine ispranog mineralnog dušika su najveće u uvjetima natapanja nasada jabuka, te variraju od 13,5 do 47,7 kg N/ha, odnosno od 27 do $49 \%$ u odnosu na dušik dodan mineralnim gnojivom. Višegodišnji podaci ispiranja mineralnog dušika pri uzgoju ratarskih kultura, dominantno kukuruza, variraju u vrlo širokom rasponu od 7,2 $\mathrm{kg} \mathrm{N} / \mathrm{ha}$ do $30,5 \mathrm{~kg} \mathrm{~N} / \mathrm{ha}$, odnosno od 3 do $16 \%$ u odnosu na gnojidbu mineralnim dušikom, tablica 4, ovisno o sezonskim hidrološkim, hidropedološkim i agrotehničkim, odnosno biljno-proizvodnim uvjetima.

Utvrđene razlike, kao što je rečeno, mogu se dovesti u vezu s biljnim pokrovom, o čemu svjedoče i drugi brojni rezultati istraživanja. Ispiranje dušika iz tla pod travama i oraničnim kulturama za $85 \%$ je manje u odnosu na tla pod vinovom lozom, a čak za $95 \%$ je manje u odnosu na tla pod ugarom. 
Ž. Vidaček: Osjetljivost tla na propuštanje onečišćivača i ranjivost podzemne vode na onečišćenje u nizinskom području Međimurske županije

Tablica 4. Gnojidba (G) i količine ispranog mineralnog dušika (N)

Table 4 Fertilization (F) and quantities of mineral nitrogen (N)

\begin{tabular}{|c|c|c|c|c|c|c|c|c|c|}
\hline \multicolumn{1}{|c|}{$\mathrm{kg} \mathrm{N} / \mathrm{ha}$} \\
\hline VII - IX 2003. & \multicolumn{2}{|c|}{2004.} & \multicolumn{2}{|c|}{2005.} & \multicolumn{2}{c|}{2006.} & \multicolumn{2}{c|}{2007.} \\
\hline G/F & $\mathrm{N}$ & $\mathrm{G} / \mathrm{F}$ & $\mathrm{N}$ & $\mathrm{G} / \mathrm{F}$ & $\mathrm{N}$ & $\mathrm{G} / \mathrm{F}$ & $\mathrm{N}$ & $\mathrm{G} / \mathrm{F}$ & $\mathrm{N}$ \\
\hline \multicolumn{8}{|c|}{ Kontrolno polje - Control field Nedelišće } \\
\hline 42 & 13,50 & 134 & 47,67 & 67 & 31,15 & 105 & 28,23 & 93 & 46,28 \\
\hline \multicolumn{8}{|c|}{ Kontrolno polje - Control field Gornji Hrašćan } \\
\hline- & - & 293 & 23,66 & 333 & 11,48 & 170 & 11,56 & 263 & 7,39 \\
\hline \multicolumn{8}{|c|}{ Kontrolno polje - Control field Prelog } \\
\hline- & 7,84 & 239 & 26,05 & 150 & 7,22 & 186 & 30,49 & 181 & 11,35 \\
\hline
\end{tabular}

Prema vlastitim dosadašnjim istraživanjima, u uvjetima hidromelioriranog amfigleja na području dijela Istočne Slavonije, pri uzgoju ozimog ječma gnojenog sa $172 \mathrm{~kg} \mathrm{~N} / \mathrm{ha}$ isprano je $27,5 \mathrm{~kg} \mathrm{~N} / \mathrm{ha}(16 \%)$, a pri uzgoju kukuruza gnojenog sa $174 \mathrm{~kg} \mathrm{~N} / \mathrm{ha}$ isprano je $9,4 \mathrm{~kg} \mathrm{~N} / \mathrm{ha}(5,4 \%)$ Vidaček $\check{Z}$. i sur. 2008.-2009.

Potencijalni rizik od većeg onečišćenja podzemne vode mineralnim dušikom na lokalitetu Nedelišće u uvjetima natapanja potrebno je smanjiti adekvatnom N gnojidbom (vrste, količine i način primjene). Gnojidba dušikom preko tla preporuča se u više navrata s manjim količinama. Kako se radi o površini s natapanjem $\mathrm{N}$ gnojiva je moguće primijeniti i fertirigacijom.

\section{ZAKLJUČAK}

U donjem dijelu Međimurja ima najviše obradivog poljoprivrednog zemljišta $(73,94 \%)$ Ostalo su livade i pašnjaci $(26,52 \%)$. S agro ekološkog gledišta, to su poljoprivredne površine s potencijalno visokim stupnjem onečišćenja agrokemikalijama i mogućnošću onečišćenja podzemnih voda.

Na području između Gornjeg i Donjeg Međimurja i na širem području uz rijeku Muru su tla IV. klase jake osjetljivosti na propuštanje onečišćivača $s$ površine tla. U zaobalju rijeke Drave, dominiraju tla II. i III. klase slabe i umjerene osjetljivosti tla na propuštanje onečišćivača. U centralnom dijelu donjeg Međimurja se izmjenjuju II., III. i IV. klasa osjetljivosti tla na propuštanje onečišćivača. 
Ž. Vidaček: Osjetljivost tla na propuštanje onečišćivača i ranjivost podzemne vode na onečišćenje u nizinskom području Međimurske županije

Pedološki pokrov nizinskog međimurskog kraja $\mathrm{s}$ automorfnim i hidromofnim tlima različite vodopropusnosti i osjetljivosti propuštanja onečišćivača je na otvorenom jako ranjivom kvartarnom vodonosniku prosječne hidrauličke provodljivosti $7,1 \times 10^{-1} \mathrm{~cm} / \mathrm{s}$.

Godišnje količine procijeđene vode iz lizimetara sa ili bez onečišćivača $\mathrm{su}$ bile $\mathrm{u}$ petogodišnjem razdoblju na kontrolnom polju Nedelišće 126,3-281,1 mm, na kontrolnom polju Gornji Hrašćan 75,8-104,6 mm i na kontrolnom polju Prelog 116,4-197,7 mm.

Petogodišnjim stacionarnim istraživanjima utvrđeno je sljedeće: količine ispranog mineralnog dušika su najveće u uvjetima natapanja nasada jabuka, te variraju od 13,5 do $47,7 \mathrm{~kg} \mathrm{~N} / \mathrm{ha}$, odnosno od 27 do $49 \%$ u odnosu na dušik dodan mineralnim gnojivom. Višegodišnji podaci ispiranja mineralnog dušika pri uzgoju ratarskih kultura, dominantno kukuruza, variraju u vrlo širokom rasponu od 7,2 $\mathrm{kg} \mathrm{N} / \mathrm{ha}$ do $30,5 \mathrm{~kg} \mathrm{~N} / \mathrm{ha}$, odnosno od 3 do $16 \%$ u odnosu na gnojidbu mineralnim dušikom.

Potencijalni rizik od većeg onečišćenja podzemne vode mineralnim dušikom na lokalitetu Nedelišće, pri uzgoju jabuka s natapanjem, potrebno je smanjiti adekvatnom $\mathrm{N}$ gnojidbom (vrste, količine i način primjene). Gnojidba dušikom preko tla preporuča se u više navrata s manjim količinama. Kako se radi o površini $\mathrm{s}$ natapanjem dušična gnojiva je moguće primijeniti i fertirigacijom.

Podaci o osjetljivosti tla $\mathrm{i}$ ranjivosti podzemne vode na onečišćenje $\mathrm{s}$ površine poljoprivrednog tla županije prilog su regionalnom planiranju i operacionalizaciji zaštite tla i podzemnih voda od onečišćenja, obilnoj zakonskoj regulativi zaštite tla i voda i momentalno u mirovanju Programa trajnog motrenja tala Hrvatske, AZO i sur. 2008-2009. 
Ž. Vidaček: Osjetljivost tla na propuštanje onečišćivača i ranjivost podzemne vode na onečišćenje u nizinskom području Međimurske županije

\section{LITERATURA}

1. Vidaček, Ž., Mojsinović, J., Racz Z. (1984.): Utjecaj hidroelektrane Dubrava na biljnu proizvodnju, Zemljište i biljka, vol.33, No 3, 309-321, Beograd

2. Vidaček, Ž., Bogunović, M., Husnjak, S., Sraka, M., Bensa Aleksandra, Petošić, D. (2004.): Hidropedološka karta republike Hrvatske, Zavod za pedologiju Agronomskog fakulteta, Zagreb

3. Vidaček, Ž., Bensa Aleksandra, Čoga, L., Husnjak, S., Vrhovec Danijela (2008.): Studija utjecaja onečišćenja na kakvoću podzemne vode $u$ Međimurskoj županiji - utjecaj poljoprivrede na kakvoću podzemnih voda za razdoblje 2003-2007, Zavod za pedologiju Agronomskog fakulteta, Zagreb

4. Vidaček, Ž., Bogunović M., Husnjak, S., Sraka, M. Bensa Aleksandra (2008.2009.): Studija osjetljivosti tla i ranjivosti podzemnih voda na onečišćenje $s$ površine poljoprivrednog zemljišta, Zavod za pedologiju Agronomskog fakulteta, Zagreb

5. Vidaček, Ž.: (2014.-2016.): Prilog zaštiti tla i podzemnih voda u Hrvatskoj, Gazophylacium časopis za znanost, kulturu, umjetnost i gospodarstvo, God.XIX.,XX.,XXI.,br.1-4, str25-42, Zagreb

6. Agencija za zaštitu okoliša (2008.): Program trajnog motrenja tala Hrvatske s pilot projektom LIFE05 TCY/CRO/000105, Zagreb

xxx Pravilnik o utvrđivanju zona sanitarne zaštite izvorišta (NN br. 55/02)

8. xxx Pravilnik o dobroj poljoprivrednoj praksi u korištenju gnojiva (NN 56/08)

9. xxx Nitratna direktiva, (91/676/EEC) propis je Europske Unije o zaštiti voda od onečišćenja uzrokovanog nitratima iz poljoprivrednih izvora, donesen 1991. godine

Adresa autora - Author's address:

Prof.dr.sc. Željko Vidaček dipl ing. agr., pedolog, umirovljeni redoviti profesor $\mathrm{u}$ trajnom zvanju, Marija Bistrica
Primljeno - Received:

25.10.2018. 